\title{
Interactive effects of grazing and drought on desert rangelands of Tunisia
}

\author{
Mouldi Gamoun ${ }^{1,4^{*}}$ \\ Bouajila Essifi², \\ Chris Dickens ${ }^{3}$, \\ Belgacem Hanchi ${ }^{4}$ \\ ${ }^{1}$ Laboratory of Range Ecology, \\ Arid Regions Institute (IRA), \\ 4119 Medenine, Tunisia \\ ${ }^{2}$ Laboratory of Eremology \\ and Combating Desertification, \\ Arid Regions Institute (IRA), \\ 4119 Medenine, Tunisia \\ ${ }^{3}$ Institute of Natural Resources (NPC), \\ PO Box 100396, Scottsville 3209, \\ South Africa \\ ${ }^{4}$ Biology Department, \\ Faculty of Science, \\ El-Manar University, \\ 1060 Tunis, Tunisia
}

Arid rangelands worldwide regularly confront drought and overgrazing. Land degradation is mostly apparent in desert rangelands, where drought events are important and grazing influences and intrinsic vegetation change act intermittently. The objectives of this study were to determine the effects of grazing and drought stress on diversity, species richness and primary production in desert rangeland of southern Tunisia. This assessment was conducted in March 2008 (wet year) and March 2009 (dry year) both on grazed and ungrazed sites.

Diversity, species richness and biomass production exhibited bigger variation between years than among sites within two years. Although protection from grazing could slightly increase rangeland production in favorable years, the additive effects of heavy grazing and drought could result in restoration failure.

This study suggests that climatic variations, particularly droughts, control major trends in plant species composition, diversity and biomass. Under grazing, plants of desert regions are able to respond very rapidly to small drought. The latter is the most debilitating risk in desert areas.

Key words: forage production, species richness, diversity, desert rangelands

\section{INTRODUCTION}

Desert areas vary greatly in their aridity, from close to zero to more than $500 \mathrm{~mm}$ of annual rainfall. Temperature ranges from more than $50{ }^{\circ} \mathrm{C}$ to far less than $0^{\circ} \mathrm{C}$ (Ward, 2009). Le Houérou (1984) noted that in the north of the Sahara, the coefficient of the annual rainfall variation increased from 25 to $30 \%$ in the $400-500 \mathrm{~mm}$ zone and to $70-80 \%$ in the $100 \mathrm{~mm}$ belt. Likewise, the percentage of transpiration attributable to total evapotranspiration varies from 34 to $54 \%$ (Reynolds et al., 2000). In

\footnotetext{
*Corresponding author. E-mail: gamoun.mouldi@yahoo.fr
}

addition, Adams (2010) suggests that the deserts are the ultimate step following the loss of vegetation due to climatic or human induced changes that almost prevent the growth of plants.

There are several ways to approach the study of desert plants and their relationship with environmental factors (Evenari, 1985; Danin, Orshan, 1990; Smith et al., 1997). Globally, the most common and serious problem affecting drylands is overgrazing. It may be driven by economic pressure, greed, desperation, and, more rarely, ignorance (Danin, Orshan, 1990). Drought is a common event in rangelands, and severe drought is nothing characteristic of desert areas. Drought is 
a ubiquitous climatic hazard. It is a recurring climatic phenomenon, and its frequency, duration, intensity, severity and spatial extent all vary with locality and with time (Eldridge, Westoby, Stanley, 1990). Concern regarding the sensitivity of arid and semi-arid rangeland plant communities to escalating drought is valid based on the long-term vegetation shifts and slow recovery that has been documented globally (Mworiaet et al., 1997; Gamoun et al., 2011; Sasaki et al., 2013; Scasta, Rector, 2014).

In the arid zones of Africa, drought frequency and intensity have increased over the past three decades (IPCC, 2007) and may constitute one of the main drivers of the reduction in terrestrial aboveground net primary production (Webb et al., 1983). Shachak et al. (2005) found that drought and rainfall variability are external factors that change the resource base of drylands, have an effect on biodiversity transition, and can transform rangelands of predominantly palatable, perennial grasses to rangelands dominated by unpalatable perennial shrubs, annual grasses, and forbs (O’Connor, 1995).

In southern Tunisia, precipitation is extremely variable in both time and space (Le Houérou, 2009) with the result that the desert rangelands have frequent drought periods that have a marked effect on the vegetation (Gamoun et al., 2011). These desert rangelands are adapted to difficult conditions and are relatively resilient, but heavy grazing pressure can lead to reductions in biomass production (Gamoun, 2013). Therefore, drought alone cannot be responsible for desertification but would be only one factor.

Grazing has been considered to be one of the key disturbance factors resulting in rangeland degradation, an increase of spatial homogeneity of the rangelands, an alteration of rangelands function, and the loss of species diversity (Van Der Westhuizen, 2005; Roder et al., 2007; Gamoun et al., 2010a, 2012). Furthermore, intense grazing damages primary production, while trampling compacts the soil thereby reducing organic matter and increasing the extent of sandy dunes
(Gamoun et al., 2010a). A recent study which assessed the risks of desertification and used a system stability condition analysis by Ibanez et al. (2008) suggested that overgrazing is a classical agent of land desertification.

Drought and large herbivores frequently influence rangelands (Hild et al., 2001), but drought may trigger or accelerate the phenomenon of desertification (Le Houérou, 1996). Periodic drought has a more detrimental effect on vegetation change when accompanied by heavy grazing (Allen et al., 1995), whereas periodic grazing during drought has a minimal impact on herbage production (Heitschmidt et al., 2005). Furthermore, Loeser et al. (2006) showed that episodic drought interacts with grazing, leading to infrequent but biologically important shifts in plant communities and suggested that the importance of climatic variation in determining ecological effects of grazing practices and responses to grazing vary with climatic conditions (Curtin, 2002). The season and intensity of grazing in relation to species' phenological development is an important factor influencing rates of changes (Williams, 1970; Holmgren, Hutchings, 1972). Obviously, the precipitation regime can affect the impact of grazing. On a short-term basis, grazing often appears less significant than highly variable precipitation (Hutchings, Stewart, 1953; Turner, 1971; Eldridge et al., 1990).

Few studies have attempted to unravel the effects of grazing and drought on desert rangelands. It appeared that the negative effects of grazing on natality, mortality, or population turnover can be accentuated for certain species when subject to below average precipitation (Chambers, Norton, 1993).

Today, given the specter of climate change, understanding the response of vegetation to drought is a crucial challenge. Nevertheless, studies of this type remain difficult because of problems associated with drought quantification, the diverse responses of vegetation types to drought, and the synergistic effects of recent warming on plant ecosystems. Such research would be critical to designing grazing 
policies that address the resilience of desert rangelands, particularly during droughts.

In this paper, we aimed to understand the effects of drought and grazing and their interaction in the desert rangelands of southern Tunisia.

\section{MATERIALS AND METHODS}

\section{Study area}

The Elouara region is located in the southeastern part of Tunisia. These desert rangelands are usually characterized by sparse vegetation. The herbaceous layer comprises a mix of grasses, chenopodiaceous species and other plants. While both annual and perennial species occur in Elouara, perennial species strongly dominate the desert rangelands. Soils are mainly of aeolian origin and are predominantly sandy, with variable but generally small amounts of loam and gypsum. The study area has an extremely arid desert climate with a mean annual rainfall of 40-100 mm (Gamoun, 2013) of which about $70 \%$ is received during the 120 day, mid-October to mid-March growing season (Fig. 1). Average daily temperatures range from $11{ }^{\circ} \mathrm{C}$ in January to $34{ }^{\circ} \mathrm{C}$ in August, with daily maximum temperatures occasionally exceeding $40{ }^{\circ} \mathrm{C}$ during summer and daily minimum occasionally dipping below $5{ }^{\circ} \mathrm{C}$ during winter. Livestock farming is the main economic activity in Elouara and is essential to the areas for local food security. The principal animals kept are sheep, goats and camels.

\section{Sampling design and methods}

During 2008 and 2009, we conducted experiments on two ungrazed and heavily grazed sites that measured plant response to grazing and climatic variation. The protected site (1000 ha) had been protected from grazing over a 3-year period. The unprotected site, located near to the protected site, had been subjected to extensive grazing almost exclusively by sheep and goat to continuous heavily grazing by stocking rate exceeding two head.ha ${ }^{-1}$.year ${ }^{-1}$. The two selected sites had similar soil, landscape and climate.

Vegetation was monitored in spring (March) of 2008 and 2009, during the peak season of primary production. Plant cover and species composition were estimated using the pointquadrats method (Daget, Poissonet, 1971)

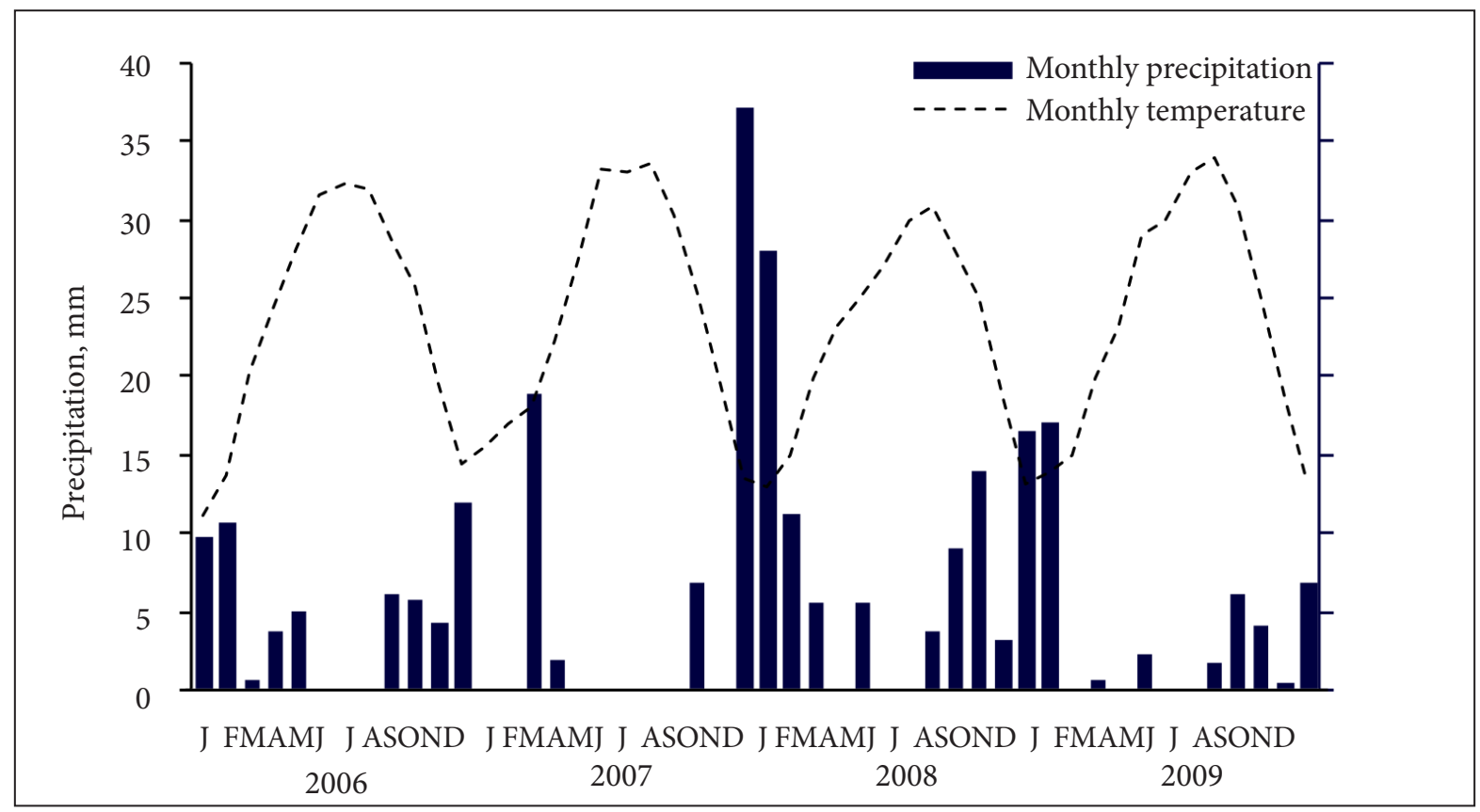

Fig. 1. Monthly precipitation $(\mathrm{mm})$ and monthly temperature $\left({ }^{\circ} \mathrm{C}\right)$ from January 2006 through December 2009 
along fourteen $20-\mathrm{m}$ long transects (100 points per transect).

Data of plant cover percentage was used to calculate the Shannon-Wiener diversity index $\left(\mathrm{H}^{\prime}\right)$. The Shannon-Weiner index which was calculated using the ordinary formula $\mathrm{H}^{\prime}=-\sum p i \mathrm{Ln} p i$, where $\mathrm{H}^{\prime}$ is the diversity index and $p i$ is the relative importance value of species $i$.

In each of the two sites, fourteen subsamples were taken from $2 \times 2 \mathrm{~m}$ quadrats to determine aboveground plant community productivity. The selection of the plot for sampling was random but measurements were done in sites not grazed during the current growing season. Aboveground biomass production measurements were made during spring of every year and were determined by cutting the herbaceous plant. The collected samples were air dried and weighed for estimation of dry matter production on $\mathrm{g} / \mathrm{m}^{2}$.

\section{Statistical analyses}

Effects of grazing and drought on primary production and plant diversity were analyzed with two-way ANOVA with an experimental wise error of 0.05 . Significant differences for all statistical tests were evaluated at the level of $P \leq 0.05$. All data analyses were conducted with the SPSS software (SPSS for Windows, Version 11.5, Chinago, IL, USA).

\section{RESULTS}

In this desert environment, the response of vegetation to short-term fluctuations in climate is varied. The two years of the study were hydrologically contrasted. The first year, 2008, was humid with $98 \mathrm{~mm}$ total rainfall, representing $130 \%$ of the annual mean (Gamoun, 2013). The second year, 2009, was on the opposite very dry, with a total annual rainfall of $40 \mathrm{~mm}$ corresponding to $50 \%$ of the annual mean. The climatic variation and grazing treatment had significant effects on diversity and production in arid zones.

\section{Diversity index}

ANOVA results confirmed significant effects of grazing intensity across the two years of treatments. The diversity index $\left(\mathrm{H}^{\prime}\right)$ varied significantly between years $(F=139.167, P<0.001)$. Similarly, grazing treatment had significant effects on the diversity index $(F=48.441$, $P<0.001)$. Diversity was less on the grazed area compared with the protected ones and tended to be higher during the wet year (2008) and lower during the dry year (2009). There

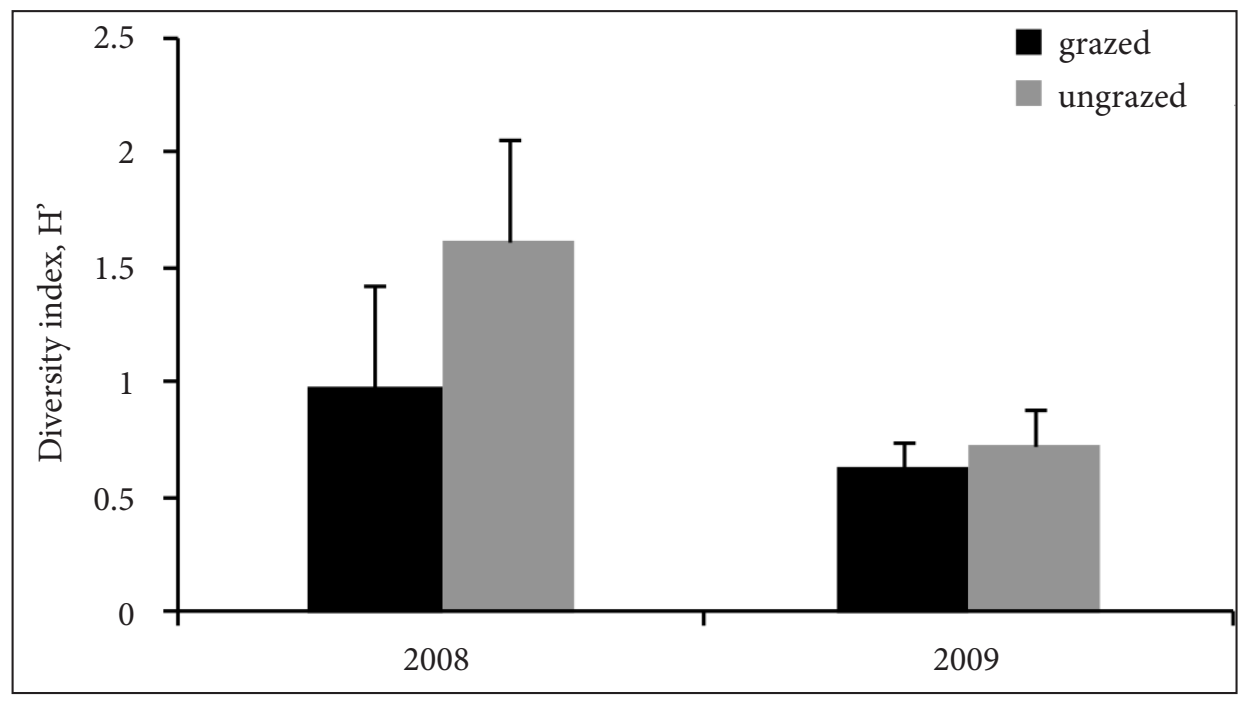

Fig. 2. Mean of diversity index (H') in grazed and ungrazed sites in 2008 and 2009. $\mathrm{H}^{\prime}$ is significantly different among grazing treatment and year $(P<0.05)$. Vertical bars represent standard errors 
was a significant interaction between grazing treatment and year on diversity $(F=25.405$, $P<0.001)$ as grazing greatly decreased diversity in 2009 compared to 2008 (Fig. 2).

\section{Species richness}

Over the two years, 29 species were recorded in the studied rangelands. Species richness ranged between 4 and 29 species per sample and was highly affected by year $(F=824.386$, $P<0.001)$ and greatly influenced by grazing $(F=405.212, P<0.001)$. Richness was the lowest in 2009, the driest year, and the highest in 2008 , the year with the highest diversity. Effects of climate and grazing were more complex, with a large year and grazing interaction $(F=84.186, P<0.001)$.

The differences in the number of species between grazing treatments were surpassed by the differences recorded between years, the flora being richer in 2008 than in 2009 (Fig. 3). In 2008, protection from grazing increased flora richness, but decreased it by $23 \%$ in 2009 (the driest year). However, heavy continuous grazing decreased flora richness, but the flora was more affected by heavy grazing combined with drought. Species richness was more affected by drought than grazing. It is absolutely that several numbers of grass species, short cycle annu- als and xerophytes species were more resistant to grazing intensity than drought.

Over the two years of our experiment, 29 species were recorded in the studied rangelands (Table). In the heavily grazed site, the species composition, initially 16 species in 2008 , decreased to just 7 species in 2009, most of them were perennial. At the ungrazed site, the composition species consisted of 29 species in 2008. Similarly, they tended to decrease during the year 2009. The biggest difference between the two sites was the disappearance of very palatable species in the heavily grazed or grazed site, such as Anabasis oropediorum (Maire), Cutandia dichotoma (Forssk.) Trab., Echiochilon fruticosum (Desf.), and Helianthemum sessiliflorum (Desf.).

The second difference showed by our study is behavior towards disturbance. It seems that several species are sensitive to disturbance whereas others are more resistant. Species in the desert landscapes are more resistant to grazing but compete less effectively for water resources.

\section{Primary production}

On the one hand, rangeland production ranged between 82.4 and $222.5 \mathrm{~g} \mathrm{DM} / \mathrm{m}^{2} / \mathrm{yr}$. On the other hand, primary production fluctuated between years $(F=57.720, P<0.001)$, but it was greater in

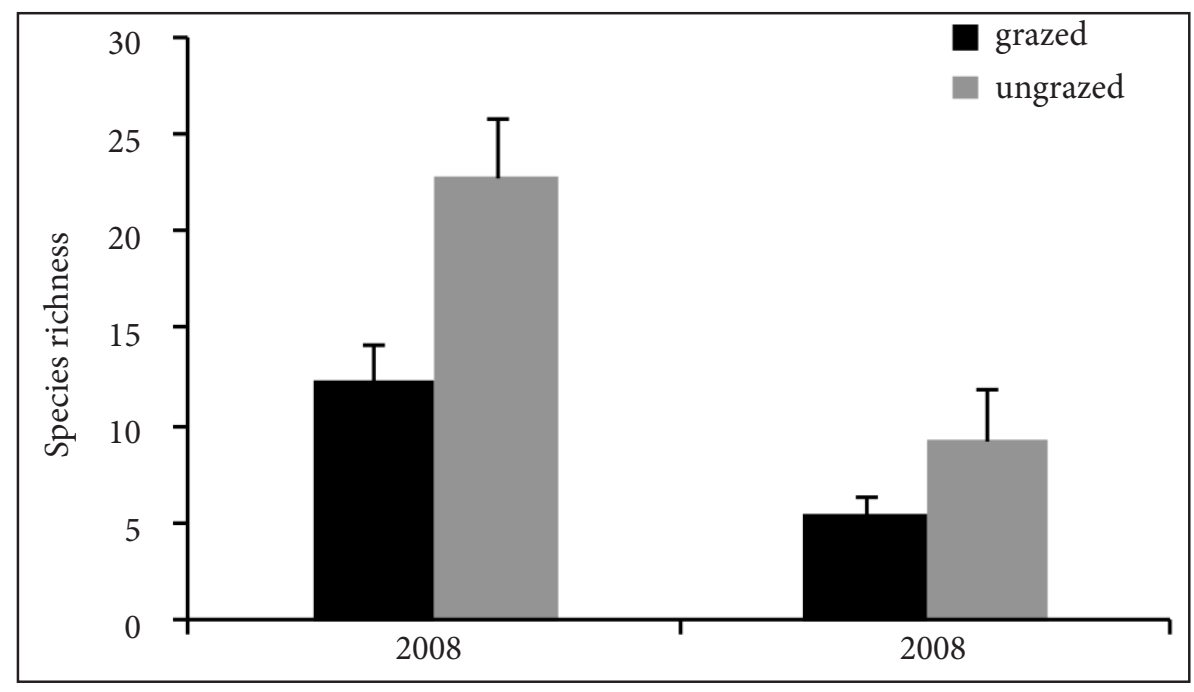

Fig. 3. Mean of species richness in grazed and ungrazed sites in 2008 and 2009. Species richness is significantly different among grazing treatment and year $(P<0.05)$. Vertical bars represent standard errors 
Table. Family, life cycle, and life form of main species recorded in grazed and ungrazed sites in 2008 and 2009

\begin{tabular}{|c|c|c|c|c|c|c|c|}
\hline \multirow{2}{*}{ Species name } & \multirow{2}{*}{ Family } & \multirow{2}{*}{$\begin{array}{l}\text { Life } \\
\text { form }\end{array}$} & \multirow{2}{*}{$\begin{array}{l}\text { Life } \\
\text { cycle }\end{array}$} & \multicolumn{2}{|c|}{ Grazed } & \multicolumn{2}{|c|}{ Ungrazed } \\
\hline & & & & 2008 & 2009 & 2008 & 2009 \\
\hline Anabasis oropediorum Maire & Chenopodiaceae & $\mathrm{Ch}$ & $\mathrm{P}$ & - & - & $*$ & $*$ \\
\hline Anacyclus clavatus Desf. & Asteraceae & Th & A & - & - & $*$ & - \\
\hline $\begin{array}{c}\text { Anacyclus cyrtolepidioides } \\
\text { Pomel }\end{array}$ & Asteraceae & $\mathrm{He}$ & A & - & - & $*$ & - \\
\hline $\begin{array}{c}\text { Anthyllis sericea Lag. subsp. } \\
\text { henoniana (Coss.) Maire }\end{array}$ & Fabaceae & $\mathrm{Ch}$ & $\mathrm{P}$ & $*$ & $*$ & $*$ & $*$ \\
\hline $\begin{array}{c}\text { Argyrolobium uniflorum } \\
\text { (Deene.) Jaub. \& Spach }\end{array}$ & Fabaceae & $\mathrm{Ch}$ & $\mathrm{P}$ & $*$ & - & $*$ & - \\
\hline Aristida ciliata Desf. & Poaceae & $\mathrm{He}$ & $\mathrm{P}$ & - & - & * & - \\
\hline Asphodelus refractus Boiss. & Liliaceae & Th & A & - & - & $*$ & - \\
\hline Asphodelus tenuifolius L. & Liliaceae & Th & A & $*$ & - & $*$ & - \\
\hline $\begin{array}{c}\text { Atractylis serratuloides Sieber } \\
\text { ex Cass }\end{array}$ & Asteraceae & $\mathrm{Ch}$ & $\mathrm{P}$ & $*$ & $*$ & $*$ & $*$ \\
\hline Bassia muricata (L.) Asch. & Chenopodiaceae & Th & A & - & - & * & - \\
\hline $\begin{array}{c}\text { Cutandia dichotoma (Forssk.) } \\
\text { Trab. }\end{array}$ & Poaceae & Th & A & - & - & * & - \\
\hline Echiochilon fruticosum Desf. & Boraginaceae & $\mathrm{Ch}$ & $\mathrm{P}$ & - & - & $*$ & $*$ \\
\hline $\begin{array}{l}\text { Enarthrocarpus clavatus Delile } \\
\text { ex Godr. }\end{array}$ & Asteraceae & Th & A & - & - & $*$ & - \\
\hline Fagonia glutinosa Delile & Zygophyllaceae & Th & A & $*$ & $*$ & $*$ & $*$ \\
\hline Gymnocarpos decander Forssk. & Caryophyllaceae & $\mathrm{Ch}$ & $\mathrm{P}$ & $*$ & $*$ & $*$ & $*$ \\
\hline $\begin{array}{c}\text { Hammada schmittiana } \\
\text { (Pomel) Ilji }\end{array}$ & Chenopodiaceae & $\mathrm{Ch}$ & $\mathrm{P}$ & * & * & * & $*$ \\
\hline $\begin{array}{c}\text { Helianthemum sessiliflorum } \\
\text { (Desf.) }\end{array}$ & Cistaceae & $\mathrm{He}$ & $\mathrm{P}$ & - & - & $*$ & $*$ \\
\hline Hernaria fontaneesii J. Gay & Caryophyllaceae & $\mathrm{He}$ & $\mathrm{P}$ & - & - & $*$ & - \\
\hline $\begin{array}{c}\text { Ifloga spicata (Forssk.) } \\
\text { Sch. Bip. }\end{array}$ & Asteraceae & Th & A & $*$ & - & $*$ & * \\
\hline $\begin{array}{c}\text { Matthiola longipetala (Vent.) } \\
\text { DC. }\end{array}$ & Brassicaceae & Th & A & - & - & $*$ & - \\
\hline Medicago minima Grufb. & Fabaceae & Th & A & * & - & * & $*$ \\
\hline Neurada procumbens L. & Neuradaceae & $\mathrm{Th}$ & A & $*$ & - & $*$ & $*$ \\
\hline Paronichia arabica (L.) DC. & Caryophyllaceae & Th & A & - & - & $*$ & - \\
\hline Plantago albicans $\mathrm{L}$. & Plantaginaceae & $\mathrm{He}$ & $\mathrm{P}$ & $*$ & - & $*$ & $*$ \\
\hline Reseda alba $\mathrm{L}$ & Resedaceae & Th & A & $*$ & - & $*$ & - \\
\hline Retama raetam (Forssk.) Webb & Fabaceae & $\mathrm{Na}$ & $\mathrm{P}$ & * & * & * & $*$ \\
\hline $\begin{array}{c}\text { Schismus barbatus (L.) } \\
\text { P. Beauv. }\end{array}$ & Poaceae & Th & A & $*$ & - & $*$ & $*$ \\
\hline Stipa parviflora Desf. & Gramineae & $\mathrm{He}$ & $\mathrm{P}$ & $*$ & - & $*$ & $*$ \\
\hline $\begin{array}{c}\text { Stipagrostis pungens (Desf.) } \\
\text { de Winter }\end{array}$ & Poaceae & $\mathrm{He}$ & $\mathrm{P}$ & $*$ & $*$ & $*$ & $*$ \\
\hline
\end{tabular}


the ungrazed than in the grazed site. Also, grazing treatment had significant effects on primary production $(F=44.048, P<0.001)$. Year-bygrazing treatment interactions were significant $(F=8.331, P<0.01)$.

As to primary production, it was lesser in the drought year of 2009 than in the nondrought year of 2008 and lesser in the grazed than in the ungrazed site as well. The only difference found thereafter was that biomass production was greater in the non-drought year 2008 in the grazed site than in ungrazed site in the driest year 2009, but very weak in the drought year under grazing. Consequently, we can deduce that grazing had a smaller influence on rangeland production than drought had. The dynamic of the vegetation was profoundly influenced by the distinct interactions between drought and grazing.

Figure 4 shows the mean production on study sites over the two-year period. The figure illustrates that the primary production was $82.4-128.8 \mathrm{~g} \mathrm{DM} / \mathrm{m}^{2} / \mathrm{yr}$ on the grazed site. While in the protected site, primary production stretched between 119.3 and $222.5 \mathrm{~g} \mathrm{DM} /$ $\mathrm{m}^{2} / \mathrm{yr}$. The difference in terms of biomass on grazed and ungrazed sites was attributed to removal by livestock. Thus, protection from grazing promotes improvement and increases the biomass production of rangelands. Again, it is evident that drought stress led to a severe decline in biomass production both in grazed and ungrazed sites.

\section{DISCUSSION}

Desert rangeland may be disturbed by overgrazing or stressed by drought. The time needed for degraded overgrazed rangelands to recover and reach an excellent condition through natural succession differs depending on the climate and vegetation type (Gamoun, Zamouri, 2014). We noticed that their dynamics presented a strong tendency to vary along with the disturbance gradient. Protected from grazing, the examined parameters: diversity index, species richness and biomass production tended to increase. This trend depends on the availability of water resources.

The results of this study show that diversity, species richness and biomass production strongly varied through time and grazing intensity,

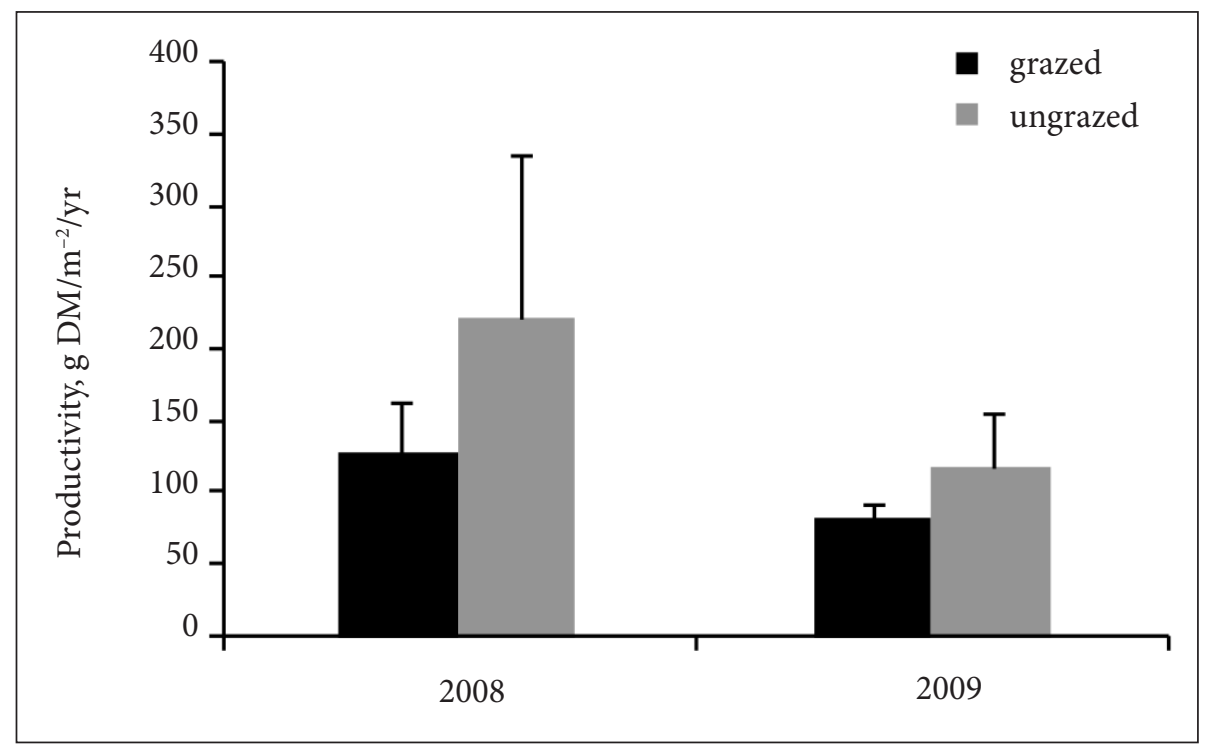

Fig. 4. Mean of biomass production $\left(\mathrm{g} \mathrm{DM} / \mathrm{m}^{2}\right)$ in grazed and ungrazed sites in 2008 and 2009. Biomass production is significantly different among grazing treatment and year $(P<0.05)$. Vertical bars represent standard errors 
with water disposal as the main driving factor, as found by Noy-Meir (1973), Le Houérou (1993), Osem et al. (2002) and Gamoun (2014). The difference between grazed and ungrazed sites was attributed to removal by livestock. However, the temporal variation was mainly due to annual and interannual differences in precipitation.

Similarly, this study demonstrated that grazing consistently reduces diversity, species richness and biomass production, whereas its effects can vary depending on the water availability for vegetation. Also, the vegetation responses varied across the two-years-study. During this period, the biomass production at peak season in the protected site from grazing was $222.5 \mathrm{~g}$ $\mathrm{DM} / \mathrm{m}^{2} / \mathrm{yr}$ in 2008 . On the contrary, biomass production in 2009, which was the driest year, diminished to reach $119.35 \mathrm{~g} \mathrm{DM} / \mathrm{m}^{2} / \mathrm{yr}$ in the same protected site. In the grazed site, biomass production fell from $128.8 \mathrm{~g} \mathrm{DM} / \mathrm{m}^{2} / \mathrm{yr}$ in 2008 to $82.45 \mathrm{~g} \mathrm{DM} / \mathrm{m}^{2} / \mathrm{yr}$ in 2009 . The effects of grazing practices were greatly influenced by interannual variation in climatic conditions, particularly precipitation. In regards of biomass production tendency, we can deduce that protection from grazing increased both of diversity and species richness in 2008, but they were affected or reduced in the dry year of 2009. Furthermore, protection in the driest year resulted in an increase in biomass and species number compared to the grazed site. This can be explained by the fact that under complete protection from grazing, some desirable changes may occur, such as an excessive litter accumulation that will change the habitat and can improve land microclimate and reduce soil evaporation. In addition, poor establishment and slow growth under extreme temperature can be supported by microclimate amelioration using other vegetation as nurse plants to provide shade or windbreaks and surface contouring. Thus, protection from grazing can improve the microclimate in the desert areas.

Weak biomass production in arid rangeland also has been reported for desert regions with less rainfall and less diversity, ranging from zero to several hundred grams per square meter (Noy-Meir, 1973).
The serious effects of grazing on diversity, species richness and primary production observed during this experiment can be interpreted as the outcome of the interaction between grazing and drought stress. There is a basic assumption that, with a low primary production, plant growth and diversity is limited by soil resources (mainly water and minerals). Thus, in the low biomass production range, in which the gradual increase in richness can be related to increasing availability of soil resources, richness was either unaffected or slightly reduced by grazing, most likely due to plant removal and trampling (NoyMeir, 1990). In 2009, diversity, species richness and biomass production continues to drop under grazing, probably in response to poor soil resources and to a parallel reduction of rangeland heterogeneity, due to removal by grazing of the palatable larger species. Without grazing, on the other hand, biomass production did not continue to increase in the driest year and was generally lower than in the grazed site during the wet year 2008. Thus, grazing interacts with hydrology, which had a larger effect on the vegetation in 2009. Decline in vegetation dynamic with drought could indicate reduced seed production, induced seed dormancy, or lack of seed viability (Hild et al., 2001). All together, these trends can be interpreted as a regressive succession due to grazing during the driest year. Within this context, it can be argued that unpalatable species are more susceptible to availability of resources and grazing. Otherwise, under continuous heavy grazing, in addition to a clear decrease of precipitation, the vegetation and growth of the palatable grasses are restricted due to selective grazing by livestock. Under long-term intensive grazing, a shift in species composition frequently involves the replacement of palatable plants by unpalatable plants and woody perennial species (Noy-Meir, 1995). Selective grazing can decrease diversity, but strong selection for grazing-tolerant plant species reinforced by stress drought greatly reduces diversity. Otherwise, during a drought and continuous grazing, the animal is compelled to supply large quantities of food while grazing any plant. 
The drought conditions of 2009 reinforced grazing intensity which could greatly influence community responses to local disturbance, leading to a further loss of vegetation, intensifying the degradation process. A persistence of the present perennial species in pastures has often been considered to relate simply to its deeper root system and higher drought tolerance.

Previous research on rangelands has shown generally that grazing is a secondary factor affecting ecosystem processes whereas drought is a primary factor (Biondini et al., 1998; Heitschmidt et al., 1999). Our results highly supported this conclusion with regards to grazing impacts but not as it relates to drought.

\section{CONCLUSIONS}

Protection can provide barriers against the impacts of drought and desertification by reducing grazing pressure on land and thus reducing desert formation and by maintaining populations of drought resistant plants to serve as emergency food during drought or for restoration. Droughts cause immediate problems of their own and also, in combination with factors such as changes in grazing pressure, create an increased tendency for desertification.

This study confirms previous observations that climatic variations, particularly droughts, control major trends in plant species composition, diversity and primary production. Under grazing, plants of desert regions are able to respond very rapidly to small drought. In desert rangeland, overgrazing, when pasture growth is restricted during the drought or summer high temperatures, can be an increasing degradation factor. In general, this study confirms that drought is the most debilitating risk in desert areas and that rangelands vegetation may be greatly depleted by the combined effects of grazing and drought.

Desert rangelands support the majority of Tunisia's livestock production and provide important wildlife habitats. Today, rangelands productivity is not satisfactory to feed the animals, and fodder supplies augment every year.
Forage production and grazing capacity also vary between years, depending on amount and distribution of rainfall and other climatic factors. The protection of natural vegetation may be the fastest and most cost-effective way of halting desert formation. Thus, understanding the interacting effects of drought and grazing on vegetation is essential for improving rangeland management. Accordingly, it is necessary that plants require a period of rest after drought and heavy grazing.

Received 14 March 2016 Accepted 20 June 2016

\section{References}

1. Adams J. Vegetation-climate interaction. How plants make the global environment. 2nd ed. Chichester, UK: Praxis Publishing Ltd; 2010.

2. Allen RB, Wilson JB, Mason CR. Vegetation change following exclusion of grazing animals in depleted grassland, Central Otago, New Zealand. J Veg Sci. 1995; 6: 615-26.

3. Bainbridge DA. Guide for desert and dryland restoration: New hope for arid lands. Washington, DC, USA: Island Press; 2007.

4. Biondini ME, Patton BD, Nyren PE. Grazing intensity and ecosystem processes in a northern mixed-grass prairie, USA. Ecol Appl. 1998; 8: 469-79.

5. Chambers JC, Norton EB. Effects of grazing and drought on population dynamics of salt desert shrub species on the desert experimental ranges, Utah. J Arid Environ. 1993; 24: 261-75.

6. Curtin CG. Livestock grazing, rest, and restoration in arid landscapes. Conserv Biol. 2002; 16: $840-2$.

7. Daget $\mathrm{P}$, Poissonet J. Une méthode d'analyse phytologique des prairies. Critères d'application. Annales Agronomiques. 1971; 22: 5-41.

8. Danin A, Orshan G. The distribution of Raunkiaer life forms in Israel in relation to the environment. J Veg Sci. 1990; 1: 41-8.

9. Eldridge DJ, Westoby M, Stanley RJ. Population dynamics of the perennial rangeland shrubs 
Atriplex vesicaria, Maireana astrotncha and $M$. pyramidata under grazing, 1980-1987. J Appl Ecol. 1990; 27: 502-12.

10. Evenari M. Adaptations of plants and animals to the desert environment. In: Evenari $\mathrm{M}$, Noy-Meir I, Goodall DW, editors. Hot deserts and arid shrub-lands. Amsterdam: Elsevier; 1985. p. 79-92.

11. Gamoun M. Management and resilience of Saharan rangelands: South Tunisia. Fourrages. 2013; 216: 321-8.

12. Gamoun M. Grazing intensity effects on the vegetation in desert rangelands of Southern Tunisia. J Arid Land. 2014; 6: 324-33.

13. Gamoun M, Hanchi B, Neffati M. Dynamic of plant communities in Saharan rangelands of Tunisia. Arid Ecosystems. 2012; 2: 105-10.

14. Gamoun M, Tarhouni M, Ouled Belgacem A, Hanchi B, Neffati M. Response of different arid rangelands to protection and drought. Arid Land Res Manag. 2011; 25: 372-8.

15. Gamoun M, Tarhouni M, Ouled Belgacem A, Hanchi B, Neffati M. Effects of grazing and trampling on primary production and soil surface in North African rangelands. Ekologia. 2010; 29: 219-26.

16. Gamoun M, Zamouri J. The effects of drought on plant communities in the desert rangelands of Tunisia. In: Gaur RK, Sharma P, editors. Approaches to plant stress and their management. Springer India; 2014. p. 207-17.

17. Heitschmidt RK, Haferkamp MR, Karl MG, Hild AL. Drought and grazing: I. Effects on quantity of forage produced. J Range Manag. 1999; 52: 440-6.

18. Heitschmidt RK, Klement KD, Haferkamp MR. Interactive effects of drought and grazing on Northern Great Plains Rangelands. Rangeland Ecol Manage. 2005; 58: 11-19.

19. Hild AL, Karl MG, Haferkamp MR, Heitschmidt RK. Drought and grazing III: Root dynamics and germinable seed bank. J Range Manage. 2001; 54: 292-8.

20. Holmgren RC, Hutchings SS. Salt desert shrub response to grazing use. Wildland shrubs: their biology and utilization. 1972. p. 153-165. Technical Report INT-1, USDA Forest Service, Intermountain Forest and Ranges Experiment Station, Ogden, Utah.

21. Hutchings SS, Stewart G. Increasing forage yields and sheep production on intermountain winter ranges. U.S. Agricultural Circular. 1953; 925: 63.

22. Ibanez J, Martinez J, Puigdefabregas J. Assessing desertification risk using system stability condition analysis. Ecol Model. 2008; 213: 180-98.

23. IPCC. Climate Change 2007. The physical science basis. Contribution of Working Group I to the Fourth Assessment Report of the Intergovernmental Panel on Climate Change. Cambridge: Cambridge University Press; 2007.

24. Le Houérou HN. Rain use efficiency: a unifying concept in arid-land ecology. J Arid Environ. 1984; 7: 213-47.

25. Le Houérou HN. Climate change, drought and desertification. J Arid Environ. 1996; 34: 133-85.

26. Le Houérou HN. Bioclimatology and biogeography of Africa. Springer-Verlag Berlin Heidelberg; 2009. 241 p.

27. Le Houérou HN. Grazing lands of the Mediterranean Basin. In: Coupland RT, editor. Natural grasslands: eastern hemisphere. Amsterdam: Elsevier; 1993. p. 171-96.

28. Loeser MR, Sisk TD, Crews TE. Impact of grazing intensity during drought in an Arizona Grassland. Conserv Biol. 2006; 21: 87-97.

29. Mworia JK, Mnene WN, Musembi DK, Reid RS. Resilience of soils and vegetation subjected to different grazing intensities in a semiarid rangeland of Kenya. Afr J Range Forage Sci. 1997; 14: 26-31.

30. Noy-Meir I. Desert ecosystems: environment and producers. Annu Rev Ecol Syst. 1973; 4: 25-52.

31. Noy-Meir I. Responses of two semiarid rangeland communities to protection from grazing. Isr J Bot. 1990; 39: 431-42.

32. Noy-Meir I. Interactive effects of fire and grazing on structure and diversity of Mediterranean grasslands. J Veget Sci. 1995; 6: 701-10. 
33. O'Connor TG. Transformation of savanna grassland by drought and grazing. Afr J Range Forage Sci. 1995; 12: 53-60.

34. Osem Y, Perevolotsky A, Kigel J. Grazing effect on diversity of annual plant communities in a semi-arid rangeland: Interactions with small-scale spatial and temporal variation in primary productivity. J Ecol. 2002; 90: 936-46.

35. Reynolds JF, Kemp PR, Tenhunen JD. Effects of long-term rainfall variability on evapotranspiration and soil water distribution in the Chihuahuan Desert: a modeling analysis. Plant Ecol. 2000; 150: 145-59.

36. Röder A, Kuemmerleb T, Hilla J, Papanastasisc VP, Tsiourlis GM. Adaptation of a grazing gradient concept to heterogeneous Mediterranean rangelands using cost surface modeling. Ecol Model. 2007; 204: 387-98.

37. Sam Lake P. Drought and aquatic ecosystems: effects and responses. John Wiley \& Sons Ltd.; 2011.

38. Sasaki T, Ohkuro T, Kakinuma K, Okayasu T, Jamsran U, Takeuchi K. Vegetation in a postecological threshold state may not recover after short-term livestock exclusion in mongolian rangelands. Arid Land Res Manage. 2013; 27: $101-10$.

39. Scasta JD, Rector BS. Drought and ecological site interaction on plant composition of a semi-arid rangeland. Arid Land Res Manage. 2014; 28: 197-215.

40. Shachak M, Gosz JR, Pickett STA, Perevolotsky A. Biodiversity in drylands: Toward $a$ unified framework. Oxford University Press Inc.; 2005.

41. Smith SD, Anderson JE, Monson RK. Physiological ecology of North American desert plants. Berlin: Springer; 1997.

42. SPSS Inc, 2002, Systat, version 11.5. SPSS Inc., Chicago, IL.

43. Turner GT. Soil and grazing influence of climatic factors one the reaction of desert shrubs to grazing by sheep. J Range Manage. 1971; 24: 31-7.

44. Van Der Westhuizen HC, Snyman HA, Fouche HJ. A degradation gradient for the assessment of rangeland condition of a semi- arid sourveld in southern Africa. Afr J Range Forage Sci. 2005; 22: 47-58.

45. Ward D. The biology of deserts. CPI Antony Rowe, Chippenham, Wiltshire; 2009.

46. Webb WL, Lauenroth WK, Szarek SR, Kinerson RS. Primary production and abiotic controls in forests, grasslands, and desert ecosystems in the United States. Ecology. 1983; 64: 134-51.

47. Williams OB. Population dynamics of two perennial grasses in Australian semi-arid grasslands. J Ecol. 1970; 58: 869-75.

\section{Mouldi Gamoun, Bouajila Essifi, Chris Dickens, Belgacem Hanchi}

\section{GANYMO IR SAUSROS INTERAKTYVUS POVEIKIS DYKUMŲ GANYKLOMS TUNISE}

\section{Santrauka}

Sauso klimato ganyklos visame pasaulyje nuolat susiduria su sausra ir per dideliu nuganymu. Žemès degradacija labiausiai matoma dykumų ganyklose, kur sausros reiškiniai yra svarbūs, o ganymo poveikis ir būdingos augmenijos pokytis veikia protarpiais. Šio tyrimo tikslas buvo nustatyti ganymo ir sausros streso poveikị augalų ịvairovei, rūšių gausumui ir pirminei produkcijai dykumų ganyklose pietų Tunise. Vertinimas atliktas 2008 (drėgnasis metas) ir 2009 (sausasis metas) metų kovo ménesi ganomose ir neganomose vietovėse. Augalų ìvairovè, rūšių gausumas ir biomasès produkcija pasižymejjo didesniu pokyčiu atskirais metais negu vietovèse per dvejus metus. Nors apsauga nuo ganymo galètų kažkiek padidinti ganyklų produkciją palankiais metais, tačiau didelis ganymas ir sausra gali apsunkinti augalų atkūrimą. Šis tyrimas atskleide, kad klimato pokyčiai, ypač sausra, kontroliuoja pagrindines augalų rūšių sudèties, ịvairovès ir biomasès tendencijas. Dèl ganymo dykumų regiono augalai gali labai greitai reaguoti ì mažą sausrą. Šis pavojus yra labiausiai sekinantis dykumų vietovèse.

Raktažodžiai: ganykla, augalų ịvairovè, sausra, žemès degradacija 